\title{
An Analysis of Non-Performing Assets and Recovery Performance of Self Help Group Bank Linkage Programme- Unique Preference to North Eastern Region of India
}

\author{
Tiken Das ${ }^{1}$
}

\begin{abstract}
Access to financial markets is important for poor people. Like all economic agents, low-income households and microenterprise can benefit from credit, saving and insurance services. But financial markets, because of their special features, often serve poor people badly, since poor people often have insufficient traditional forms of collateral such as physical assets to offer. But the case of informal financial institutions is different as they have greater alternatives to accept as collaterals such as labor of the borrowers. Thus the poor generally excluded from the formal financial institutions and have to depend on informal sector. Microfinance is gathering impetus to become a significant strength in India. The Self Help Group model with bank lending to groups of poor women without collateral has become an accepted part of rural finance. In spite of being successful, there are still disparities in the program in its level of progress across different parts of the country, including the north east India (NER). The SHGs-BLP was concentrated among the southern states (SR) and its performance was not satisfactory among the NE states. The SR achieved higher amount of saving balance of SHGs with banks in comparison with NER. Similarly, the amount of loan disbursed to SHGs by banks was also higher in SR. Thus naturally one point come to mind is that, does amount of NPAs is lower and recovery performance is satisfactory in NER compare to SR. In this paper we analyzed the NPAs and recovery performance of SHGs in SR and NER of India. The researcher studied the same by taking four years data of NABARD. We found that although amount of saving balance of SHGs with banks and amount of loan disbursed to SHGs by banks was lower in NER in compare with SR, but the share of NPAs to total loans outstanding was higher and percentage of recovery to demand of total SHGs was lower in NER. In recent times there has been an improvement of situation of NPAs and recovery rate in NER. However this enhancement was not comparable with SR of India. Consequently, one point come to mind is that, does because of higher NPAs and lower recovery rate, SHGs-BLP had not achieved reasonable achievement in NER of India.
\end{abstract}

Keywords: Microfinance, Non-Performing Assets, Self Help Group, Recovery Rate

\section{Introduction}

Access to financial markets is important for poor people. Like all economic agents, low-income households and microenterprise can benefit from credit, saving and insurance services. Such services help to manage risk and to smooth consumption and allow people to take advantage of profitable business opportunities and increase their earnings potential. But financial markets, because of their special features, often serve poor people badly, since poor people often have insufficient traditional forms of collateral such as physical assets to offer. They are often excluded from traditional financial markets because transaction costs are often high relative to the small loans typically demanded by poor people. And in areas where population density is low, physical access to banking services can be very difficult. Apart from that, because of the Information Asymmetry $^{2}$ the bank faces two types of risk- Voluntary ${ }^{3}$ and Involuntary ${ }^{4}$. These risks make the acceptance of collateral necessary for the lenders. In case of those who are living below poverty line, have little or no asset to be provided as collateral. This is the case that makes them excluded from the credit markets.

But the case of informal financial institutions is different as they have greater alternatives to accept as collaterals such as labor of the borrowers. Moreover the informal money lenders have somewhat greater information about the clients, as their lending operation generally stipulated local areas. Thus the poor generally excluded from the formal financial institutions and have to depend on informal sector.

\footnotetext{
${ }^{1}$ Research Associate at North Eastern Social Research Centre, Guwahati, India

${ }^{2}$ Information Asymmetry deals with the study of decisions in transactions where one party has more or better information than the other. This creates an imbalance of power in transactions which can sometimes cause the transactions to go away. Examples of this problem are adverse selection and moral hazard.

${ }^{3}$ Voluntary or strategic default is a situation when the borrower can repay the debt in principal, but simply does not find his interest to do so. Such a state of default is especially pertinent in context, where the legal system of loan enforcement is weak.

${ }^{4}$ Involuntary defaults are due to the inability of the borrowers to repay loan. This may be due to the failure of the economic activity where the loan amount is invested or due to the use of borrowed amount in some other activities for which it was not borrowed.
} 
In India, since the early national plans, successive governments have emphasized the link between improving access to finance and reducing poverty. The need to improve financial access for India's poor motivated the establishment of a vast network of rural cooperative credit banks in the 1950s, followed by a drive to nationalize commercial banks, launched in 1969. This created thousands of new bank branches in rural areas across the country. In 1980 subsidized credit programs were attempted, notable examples being the Integrated Rural Development Programme 5 (IRDP) in India. For IRDP, repayment rates fell below 60\% in 1989 and came down to just $31 \%$ by 2001 . The 1990 s saw the partial deregulation of interest rates, increased competition in the banking sector and new microfinance approaches that combine the safety and reliability of formal finance with the convenience and flexibility of informal finance.

Access to finance for the rural poor has improved somewhat over the past decades. But the vast majority of India's rural poor still do not have access to either formal finance or microfinance. According to Rural Finance Access Survey (2003), 70 percent of marginal/landless farmers do not have a bank account; 87 percent have no access to credit from a formal source. As a result, they are forced to rely on informal finance, mainly from moneylenders who charge exorbitant rates of interest.

In light of the inefficiencies that characterized India's rural finance markets and the relative lack of success of formal rural finance institutions in delivering finance to the poor, Non-Governmental Organizations (NGOs), financial institutions, and government have made efforts, in partnership, to develop new financial delivery approaches. These approaches or "microfinance" programs have been designed to overcome some of the risks and costs associated with formal financing, and also to overcome the tyranny of collateral. They involve providing thrift, credit, and other financial services and products of very small amounts to the poor, with the aim of raising income levels and improving living standards. One approach to microfinance that has gained prominence in recent years is the Self-Help Groups- Bank Linkage Programmme (SHGs-BLP). Over the last ten years, SHGs-BLP has become the dominant mode of microfinance in India, and has been successful in encouraging momentous savings and high repayment rates.

Despite of being successful, there are still disparities in the programme in its level of progress across different regions particularly between North Eastern Region ${ }^{6}$ (NER) and Southern Region ${ }^{7}$ (SR) of the country. The program remains concentrated in the southern states of India. The SHGs-BLP has been operating in India since 1992-93, but has gained momentum only since 1997-1998. Right from the inception, the program has been a major success in south India (Bansal, 2003). The SHGs-BLP since its beginning has been predominant in certain states, showing spatial preferences especially for the southern region- Andhra Pradesh, Tamil Nadu, Kerala and Karnataka (Fouillet \& Augsburg, March 2007). The southern region accounts for $65 \%$ of the SHGs linked and over $75 \%$ of the amount disbursed (Basu \& Srivastava, June, 2005). With $48 \%$ of the SHGs linked to the bank from the southern region only, among the six regions ${ }^{8}$ comprising the entire country (Datta, July 2009). In contrast, the NER accounts for $0.6 \%$ of the SHGs and $0.3 \%$ of the amount.

\section{The NABARD Sponsored Self Help Group-Bank Linkage Model}

Due to the failure of the earlier attempts to provide subsidized credit to the rural people through the formal financial institutions effectively made it necessary to search an alternative method to provide credit to this section of population. National Bank for Agriculture and Rural Development (NABARD) made an investigation in the latter part of 1980s and it found that in past the poor tended to come together in a varity of informal ways for pooling their savings and dispending small and unsecured loans at varying cost to the group members on the basis of needs (Thorat, 2006). Not only in India in some other countries also were such groups existed. At the time of financial reform several NGOs were working in some parts of the country to organize the poor people in this way. These organizations of the poor people were popularly known as Self Help Groups (SHGs).

The first official interest in informal group lending in India took shape in 1986-87 when NABARD supported and financed an Action Research Project as "Savings and Credit Managements of SHGs" of Mysore Resettlement and Development Agency (MYRADA). In 1988-89, NABARD undertook a survey of 43 NGOs spread over 11 states in India to study the functioning of the SHGs and possibilities of collaboration between banks and SHGs in the mobilization of rural savings and improving delivery of credit to the poor (Dasgupta,

\footnotetext{
${ }^{5}$ IRDP launched on October $2^{\text {nd }}, 1980$ all over the country. The objective of IRDP is to enable identified rural poor families to cross the poverty line by providing productive assets and inputs to the target groups. The assets which could be in primary, secondary or tertiary sector are provided through financial assistance in the form of subsidy by the government and term credit advanced by financial institutions. The scheme is merged with another scheme named Swarnajayanti Gram Swarojagar Yojana since 1999.

${ }^{6}$ Northeast India refers to the eastern most region of India consisting of the contiguous eight sister states. The eight sister states are Assam, Meghalaya, Mizoram, Nagaland, Manipur, Tripura, Sikkim and Arunachal Pradesh.

${ }^{7}$ Southern India is the area encompassing India's states of Andhra Pradesh, Karnataka, Kerala, Tamil Nadu and Pondicherry (NABARD, 2008-09).

${ }^{8}$ Six regions namely- Northern Region, North Eastern Region, Eastern Region, Western Region, Central Region and Southern Region
} 
2001). Encouraged by survey results, NABARD impressed upon the Reserve Bank of India (RBI) to come out with a circular on July 24, 1991 advising the commercial banks to extend credit to the SHGs under the pilot project of NABARD (Dasqupta,2001). Under this pilot project, NABARD put the objective to link 500 SHGs to banks by 1991-92. In addition to the commercial banks, the project was also extended to the Regional Rural Banks (RRBs) in 1993. In this way, the SHGs in India were linked to the formal financial institutions for the first time (Dasgupta, 2001).

To formalize the mechanism further the RBI set up a Working Group in November 1994 to review the functioning of NGOs and SHGs and make suitable recommendations for expanding their activities and deepening their role in rural sector. The Working Group came up with the recommendation that the linkage programme should be encouraged more as it provides easier savings and credit facilities and has the potential of achieving $100 \%$ repayment rate. Accepting the recommendation of Working Group in April, 1996, the RBI issued instructions to the commercial banks that they should consider SHGs functioning as a main stream activity under their priority sector lending portfolio (Satish, 2005).

\section{Advancement Under Self Help Group- Bank Linkage Programme In Recent Times}

The initiative of 1992 to make the traditional and formal banks to extend financial services to deprived sections through informal SHGs, has now blossomed into a "monolith" micro finance initiative. It has been acknowledged as decentralized, cost effective and fastest growing microfinance in the world, enabling over 103 million poor household's access to a variety of sustainable financial services from the banking system by becoming members of nearly 8 million SHGs. The linkage with banks has provided the members of the groups the facility of not only pooling their thrift/savings and access to credit from the banking system, but also created a platform through which they could launch a number of livelihood initiatives and also facilitate the empowerment process.

In this section we analyzed the performance of SHGs-BLP by taking SHGs saving with banks, loan disbursed to SHGs and loans outstanding against SHGs. Apart from that we presented a graphical analysis of saving balance, loan disbursed and loan outstanding.

Under the SHGs-BLP, as on $31^{\text {st }}$ March, 2012 over 103 million rural households have now access to regular savings through 7.96 million SHGs linked to banks. About $27 \%$ of these SHGs are savings linked through the Swarnajayanti Gram Swarozgar Yojana (SGSY) programme- the rural poverty alleviation programme of the government of India where predominantly households below the poverty line are admitted as members.

Table-1.1: Overall Progress under SHG-Bank Linkage for last 3 years

(Amount Rs in crore/Number in lakh)

\begin{tabular}{|c|c|c|c|c|c|c|c|}
\hline \multirow{2}{*}{\multicolumn{2}{|c|}{ Particulars }} & \multicolumn{2}{|c|}{ 2009-10 } & \multicolumn{2}{|c|}{$2010-11$} & \multicolumn{2}{|c|}{ 2011-12 } \\
\hline & & No. of SHGs & Amount & No. of SHGs & Amount & No. of SHGs & Amount \\
\hline \multirow{3}{*}{$\begin{array}{l}\text { SHG Saving } \\
\text { with Banks as } \\
\text { on } 31^{\text {st }} \text { March }\end{array}$} & Total SHGs & $\begin{array}{c}69.53 \\
(13.6 \%)\end{array}$ & $\begin{array}{l}6198.71 \\
(11.8 \%)\end{array}$ & $74.62(7.3 \%)$ & $\begin{array}{l}7016.30 \\
(13.2 \%)\end{array}$ & $79.60(6.7 \%)$ & $\begin{array}{c}6551.41(- \\
6.7 \%)\end{array}$ \\
\hline & $\begin{array}{l}\text { Of which } \\
\text { SGSY } \\
\text { Groups }\end{array}$ & $\begin{array}{c}16.94 \\
(12.5 \%)\end{array}$ & $\begin{array}{c}1292.62(- \\
17.3 \%)\end{array}$ & $20.23(19.4 \%)$ & $\begin{array}{l}1817.12 \\
(40.6 \%)\end{array}$ & $21.23(5.0 \%)$ & $\begin{array}{c}1395.25(- \\
23.2 \%)\end{array}$ \\
\hline & $\begin{array}{l}\% \text { of SGSY } \\
\text { Groups to } \\
\text { Total }\end{array}$ & 24.4 & 20.9 & 27.1 & 25.9 & 26.7 & 21.3 \\
\hline \multirow{3}{*}{$\begin{array}{l}\text { Loans Disbursed } \\
\text { to SHGs during } \\
\text { the year }\end{array}$} & Total SHGs & $\begin{array}{c}15.87 \\
1.4 \%)\end{array}$ & $\begin{array}{l}14453.3 \\
(17.9 \%)\end{array}$ & $\begin{array}{c}11.96 \\
24.6 \%)\end{array}$ & $\begin{array}{c}14547.73 \\
(0.01 \%)\end{array}$ & $\begin{array}{c}11.48 \\
4 \%)\end{array}$ & $\begin{array}{c}16534.77 \\
(13.7 \%)\end{array}$ \\
\hline & $\begin{array}{l}\text { Of which } \\
\text { SGSY } \\
\text { Groups }\end{array}$ & $2.67(1.0 \%)$ & $2198(9.1 \%)$ & $\begin{array}{l}2.41 \\
9.9 \%)\end{array}$ & $\begin{array}{l}2480.37 \\
(12.8 \%)\end{array}$ & $\begin{array}{l}2.10 \\
12.9 \%)\end{array}$ & $\begin{array}{c}2643.56 \\
(6.6 \%)\end{array}$ \\
\hline & $\begin{array}{l}\% \text { of SGSY } \\
\text { Groups to } \\
\text { Total }\end{array}$ & 16.9 & 15.2 & 20.1 & 17.0 & 18.3 & 16.0 \\
\hline \multirow{3}{*}{$\begin{array}{l}\text { Loans } \\
\text { Outstanding } \\
\text { against SHGs as } \\
\text { on } 31^{\text {st }} \text { March }\end{array}$} & Total SHGs & $\begin{array}{c}48.51 \\
(14.8 \%)\end{array}$ & $\begin{array}{c}28038.28 \\
(23.6 \%)\end{array}$ & $\begin{array}{c}47.87 \\
1.3 \%)\end{array}$ & $\begin{array}{c}31221.17 \\
(11.4 \%)\end{array}$ & $\begin{array}{c}43.54 \\
9.0 \%)\end{array}$ & $\begin{array}{c}36340.00 \\
(16.4 \%)\end{array}$ \\
\hline & $\begin{array}{l}\text { Of which } \\
\text { SGSY } \\
\text { Groups }\end{array}$ & $\begin{array}{c}12.45 \\
(27.5 \%)\end{array}$ & $\begin{array}{c}6251.08 \\
(6.6 \%)\end{array}$ & $12.86(3.4 \%)$ & $\begin{array}{c}7829.39 \\
(25.2)\end{array}$ & $\begin{array}{l}12.16 \\
5.4)\end{array}$ & $\begin{array}{c}8054.83 \\
(2.9 \%)\end{array}$ \\
\hline & $\begin{array}{l}\% \text { of SGSY } \\
\text { Groups to } \\
\text { Total }\end{array}$ & 25.7 & 22.3 & 26.9 & 25.1 & 27.9 & 22.2 \\
\hline
\end{tabular}

Source: Status of Microfinance Programme in India, 2011-2012, NABARD; data's are edited by author 
As on $31^{\text {st }}$ March, 2012 there has been a decline in the amount of saving balance with banks to the extent of $6.7 \%$ as compared to the previous year although the number of SHGs saving linked has shown a growth of $6.7 \%$ during the year. This decline is almost entirely attributable to the groups formed under SGSY where the decline was to the extent of $23.2 \%$. The number of saving linked SHGs now stands at 7.96 million with a membership of over 103 million poor households. While bulk of these savings is used for internal lending within the group, the balance is maintained in the savings accounts with the financing banks.

Further, over 4.36 million SHGs have now access to direct credit facilities from the banks and the total bank loans outstanding against these groups is over Rs 36340 crore as on 31 March 2012 i.e. an average of Rs 83500 per group. About 1.15 million SHGs were extended fresh loans to the extent of Rs 16535 crore during 2011-12 by all banks averaging Rs 1.44 lakh per group. Although fresh lending to SHGs during the year 201112 showed an increase of $13.7 \%$ over last year, the steady decline in the number of SHGs being extended fresh loans by banks for the last three years is a matter of concern. Number of SHGs having outstanding loans with banks is also showing a decline partly due to the continued decline in the number of SHGs being extended fresh loans by banks for the last three years. While the quantum of fresh loans issued to SHGs by banks rose by $13.7 \%$ during the year 2011-12 to Rs 16535 crore (to 11.48 lakh SHGs) as against Rs 14548 crore disbursed last year (to 11.96 lakh SHGs), the number of SHGs obtaining fresh loans from banks during the year declined by $4 \%$. What causes more concern is the fact that the number has been declining during the last three years, though the rate of decline has come down from nearly $24 \%$ last year to $4 \%$ this year. The number of SHGs having loans outstanding against them from banks declined by $9 \%$ during the year to 43.54 lakh as against 47.87 lakh last year although the quantum of loans outstanding increased to Rs 36340 crore (16.4\% increase over last year). Partly the decline can be attributed to the continued decline in the number of SHGs being extended fresh loans by banks over the last three years.

Fig. 1 shows a graphical presentation of the savings, fresh loans and the loan outstanding of SHGs with banks for the last four years.

Fig.1 SHGs as on 31.3.2012- Saving and Credit

(Amount in crore rupees)

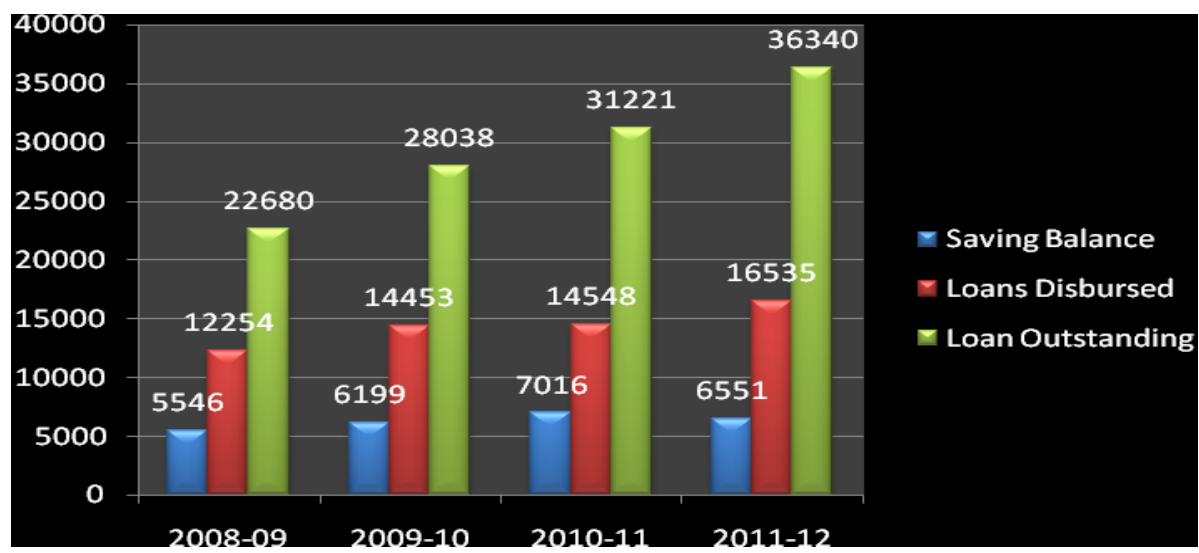

Note: Author created this fig. by taking the data from NABARD.

The name of data series is Status of Microfinance Programme in India, 2011-12.

\section{REGION-WISE PERCEPTION OF SHGs-BLP IN INDIA}

In the preceding segment we showed progress under SHGs-BLP in different time periods. We showed that the SHGs-BLP had achieved enormous success in recent times. But the problem arises, about the uneven spread of SHGs-BLP among the six regions of India. The microfinance programme is skewed in favor of the southern states, particularly Andhra Pradesh. In 2005, this state alone accounts for 39\% of the total linkage, while the northern and NER together account for only $5 \%$ of the total programme. This imbalance is an issue that requires attention.

Umdor (2010) said there is a need to review the performance of SHGs-BLP in the NER, identify factors that impede its progress and take corrective measures to improve its performance throughout the entire region. In this section we analyzed the uneven spread of SHGs-BLP in recent period among six regions of India, and particularly between southern and north eastern region of India. The paper analyzed uneven performance of SHGs-BLP by taking three variables namely- region-wise saving balance per SHGs with banks, 
region-wise bank loan per SHGs and region-wise proportion of credit linked SHGs. The researcher showed the uneven pattern of SHGs-BLP by putting the data set in bar diagram and pie chart.

The SHGs savings with banks as on $31^{\text {st }}$ March 2012 stood at Rs 6551.4 crore. Among the major states, Karnataka SHGs maintain the highest saving balance of over Rs 16000 per SHGs followed by Punjab of nearly Rs 12500 per SHGs. Among the regions, SR is highest at Rs 10080 per SHGs and northern region recorded the lowest balance of Rs 4159 per SHGs. Commercial banks account for $58 \%$ of the savings account maintained by SHGs and RRBs $27 \%$ and cooperative banks the remaining $15 \%$.

Fig. 2 Region-Wise Saving Balance per SHGs with Banks (2011-12)

(Amount in Rupees)

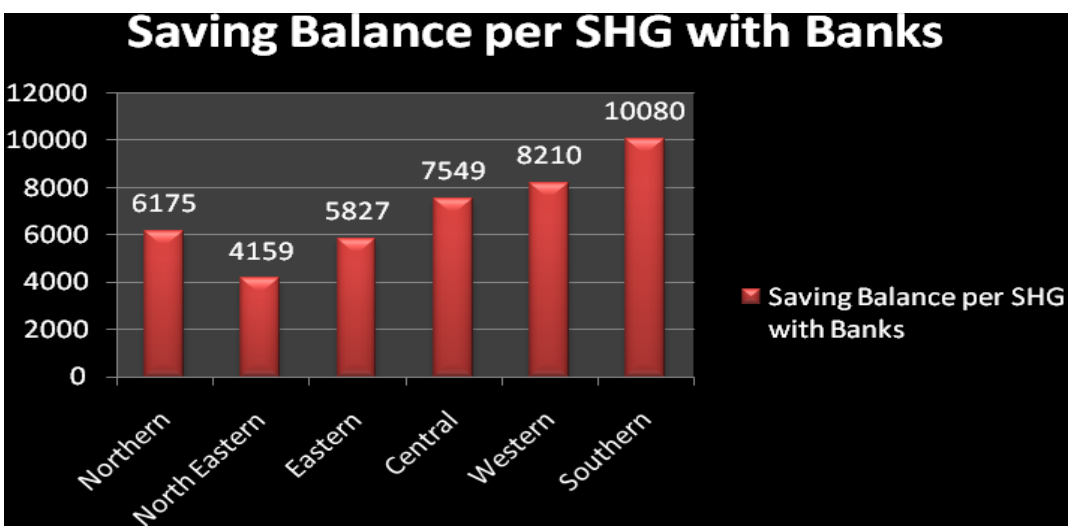

Note: Author created this fig. by taking the data from NABARD.

The name of data series is Status of Microfinance Programme in India, 2011-12.

Furthermore, the average size of fresh loans extended ranged from Rs 1.8 lakh per SHGs in the SR (Rs 1.5 lakh last year) to Rs 0.75 lakh in western region (the lowest average was Rs 0.65 lakh for eastern region) as on $31^{\text {st }}$ March 2012. The figure was Rs 0.88 lakh for NER. The average loan size across the region was Rs 1.44 lakh per SHGs. Among the financial banks, commercial banks and RRBs extended loan of Rs 1.65 lakh on an average per SHGs while cooperative banks lent Rs 0.65 lakh only per SHGs.

Fig. 3 Region-Wise Bank Loan per SHGs (2011-12)

(Amount in Rupees)

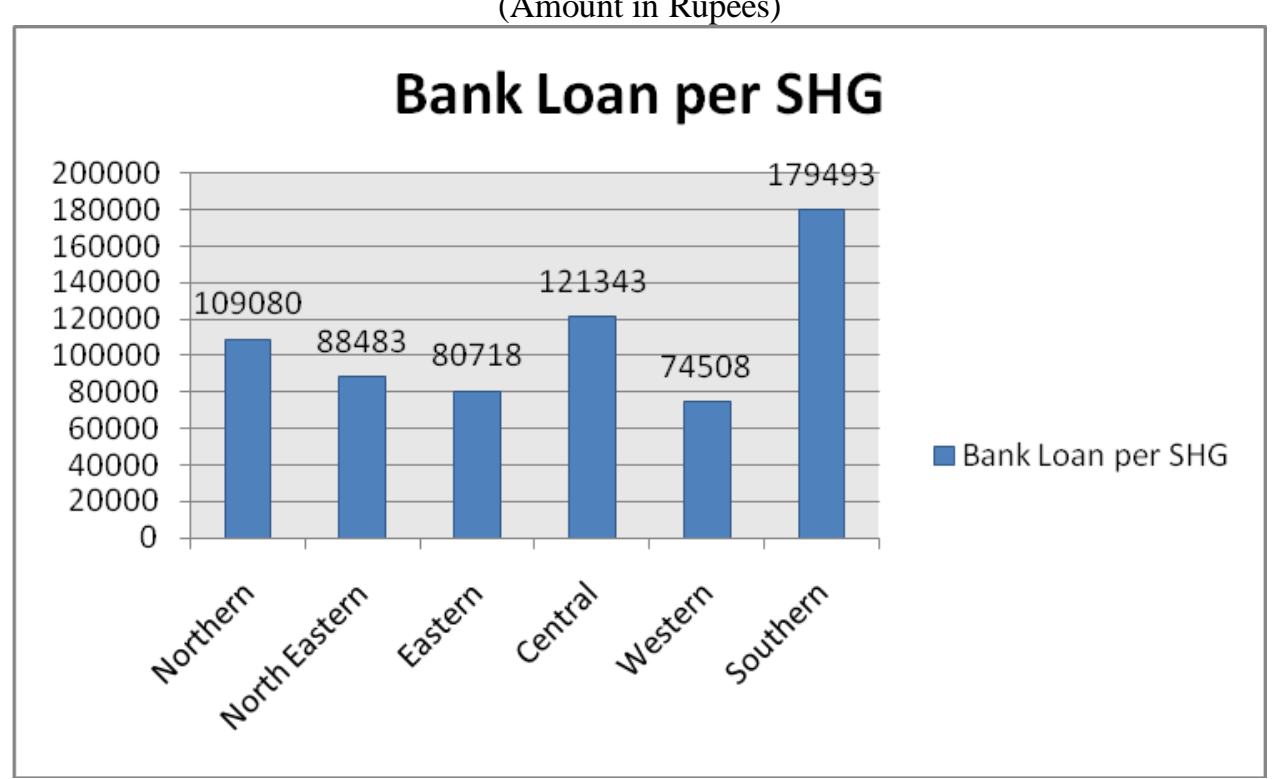

Note: Author created this fig. by taking the data from NABARD.

The name of data series is Status of Microfinance Programme in India, 2011-12.

Moreover, during the same time period, among the total number of credit linked SHGs, only $4 \%$ was located in NER. While in SR share of credit linked SHGs was 54\%, followed by eastern region (22\%). In addition, among 
the total number of credit linked SHGs, $60 \%$ was in commercial bank, $30 \%$ was in RRBs and the remaining $10 \%$ was in cooperative bank.

Fig. 4 Region-wise Credit Linked SHGs (2011-12)

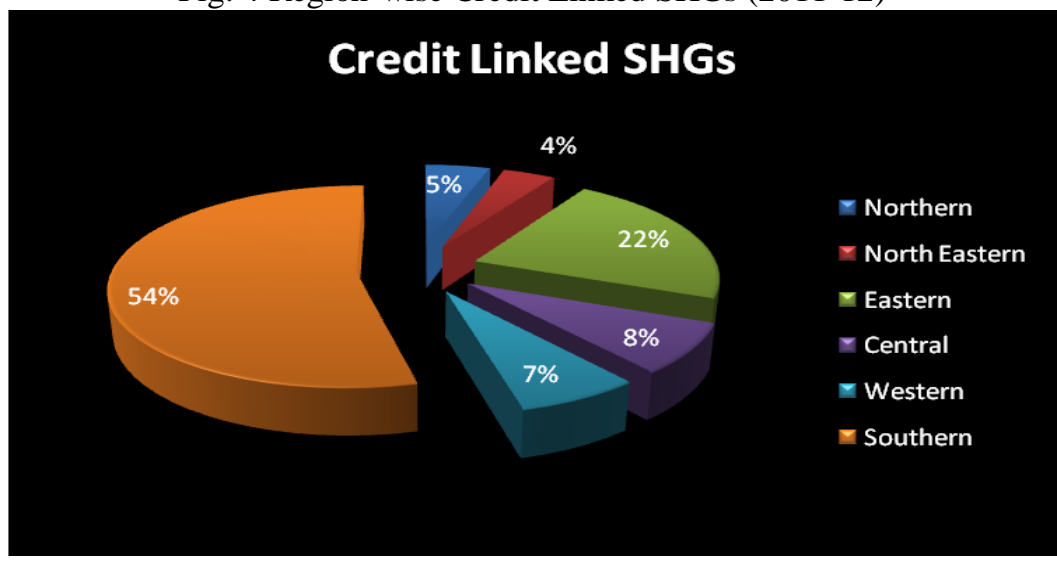

Note: Author created this fig. by taking the data from NABARD.

The name of data series is Status of Microfinance Programme in India, 2011-12.

In this section we analyzed the unequal spread of SHGs-BLP among the six regions of India, and particularly between the SR and NER of India. We found that the SHGs-BLP was concentrated among the southern states and its performance was not satisfactory among the north eastern states. At this instant the question arises about the Non-Performing Assets ${ }^{9}$ (NPAs) of SHGs against bank loan and percentage of recovery to demand of total SHGs. Does the NPAs of SHGs against bank loan is higher and percentage of recovery to demand of total SHGs is lower in NER in comparison to SR. In next part we analyzed the NPAs and recovery position of SHGs in southern and NER of India.

\section{An Analysis Of NPAs And Recovery Performance Of SHGs In Southern And North Eastern Region Of India}

In the previous section we found that, southern region achieved higher amount of saving balance of SHGs with banks in comparison with north eastern region. Similarly, the amount of loan disbursed to SHGs by banks was also higher in southern region. Thus naturally one point come to mind is that, does amount of NPAs is lower and recovery performance is satisfactory in north eastern region compare to southern region. In this section we analyzed the NPAs and recovery performance of SHGs in southern and north eastern region of India. The researcher studies the same by taking four years data of NABARD.

The increase in NPAs against loans to SHGs continued to go up during the current year as well. In absolute terms, the gross NPAs against loans to SHGs increased from Rs 1474 crore at the end of March 2011 to Rs 2213 crore by March 2012. In percentage terms it increased from $4.72 \%$ last year to $6.09 \%$ during the current year. It was only $2.9 \%$ during $2009-10$. This is a matter of concern for the microfinance sector and the causes for the declining performance of recovery should be analyzed. The total gross NPAs against loans to SHGs stood at Rs 2212.74 crore as on 31.03.2012 against the total outstanding loan of Rs 36340 crore.

During the period 2007-08 and 2008-09 in NER, the total public sector commercial bank loans outstanding against SHGs was Rs 17153.64 and Rs 24868.57 lakh respectively, and from that, portion of NPAs was around 10\%. During these periods the percentage of recovery to demand of total SHGs was $49.35 \%$ and $60.63 \%$ respectively. But during the year 2011-12, the total public sector commercial bank loans outstanding against SHGs increases to Rs 44711.86 lakh and proportion of NPAs decreases to $6.88 \%$. During the same time period, the recovery performance was somewhat increases to $71.97 \%$.

The participation of private sector commercial bank was bare minimum in north eastern microfinance programmes. Throughout the period 2011-12, only two private sector commercial banks namely Axis bank and HDFC was engaged in north eastern microfinance programmes.

Likewise, for the period of the period 2007-08 and 2008-09 in NER, the total Regional Rural bank loans outstanding against SHGs was Rs 1762.60 and Rs 15237.77 lakh respectively, and from that, portion of

\footnotetext{
9 Non-Performing Assets (NPAs) means an asset or account of a borrower, which has been classified by a bank, or financial institution as substandard, doubtful or loss asset, in accordance with the direction and guidelines relating to asset classifications issued by the Reserve Bank of India.
} 
NPAs was around 6\%. During these periods the percentage of recovery to demand of total SHGs was $78.06 \%$ and $65.14 \%$ respectively. But during the year 2011-12, the total Regional Rural bank loans outstanding against SHGs increases to Rs 46442.27 lakh and proportion of NPAs decreases to 2.98\%. During the same time period, the recovery performance was somewhat decreases to $53.5 \%$.

Table- 1.2: NPAs against Bank Loans to SHGs and Recovery Performance of Different type of Bank in North Eastern Region of India for Four Different Time Period (Amount Rs Lakh)

\begin{tabular}{|c|c|c|c|c|c|}
\hline Type of & \multirow[b]{2}{*}{ Year } & \multicolumn{3}{|c|}{ NPAs of SHGs against Bank Loan } & \multirow{2}{*}{$\begin{array}{l}\% \text { of recovery to } \\
\text { demand of total } \\
\text { SHGs }(\%)\end{array}$} \\
\hline \multirow[t]{5}{*}{$\begin{array}{l}\text { Public Sector } \\
\text { Commercial } \\
\text { Bank }\end{array}$} & & $\begin{array}{l}\text { Total loans outstanding } \\
\text { against SHGs }\end{array}$ & $\begin{array}{l}\text { Amount of } \\
\text { NPAs }\end{array}$ & $\begin{array}{l}\text { NPA as } \% \text { age } \\
\text { to total loans } \\
\mathrm{O} / \mathrm{S}\end{array}$ & \\
\hline & 2007-2008 & 17153.64 & 1714.73 & 10.0 & 49.35 \\
\hline & 2008-2009 & 24868.57 & 2633.96 & 10.59 & 60.63 \\
\hline & $2009-2010$ & 38823.85 & 2458.18 & 6.33 & 68.43 \\
\hline & 2011-2012 & 44711.86 & 3074.01 & 6.88 & 71.97 \\
\hline \multirow{6}{*}{$\begin{array}{l}\text { Private } \\
\text { Sector } \\
\text { Commercial } \\
\text { Bank }\end{array}$} & & \multicolumn{3}{|c|}{ NPAs of SHGs against Bank Loan } & \multirow{2}{*}{$\begin{array}{l}\% \text { of recovery to } \\
\text { demand of total SHGs } \\
(\%)\end{array}$} \\
\hline & Year & $\begin{array}{l}\text { Total loans outstanding } \\
\text { against SHGs }\end{array}$ & $\begin{array}{l}\text { Amount of } \\
\text { NPAs }\end{array}$ & $\begin{array}{l}\text { NPA as \% age } \\
\text { to total loans } \\
\mathrm{O} / \mathrm{S}\end{array}$ & \\
\hline & 2007-2008 & --- & --- & --- & --- \\
\hline & $2008-2009$ & 0.19 & 0.00 & 0.0 & --- \\
\hline & 2009-2010 & 2.25 & NA & NA & --- \\
\hline & 2011-2012 & 2.90 & 0.00 & 0.00 & --- \\
\hline \multirow{6}{*}{$\begin{array}{l}\text { Regional } \\
\text { Rural Bank }\end{array}$} & & \multicolumn{3}{|c|}{ NPAs of SHGs against Bank Loan } & \multirow{2}{*}{$\begin{array}{l}\% \text { of recovery to } \\
\text { demand of total SHGs } \\
(\%)\end{array}$} \\
\hline & Year & $\begin{array}{l}\text { Total loans outstanding } \\
\text { against SHGs }\end{array}$ & $\begin{array}{l}\text { Amount of } \\
\text { NPAs }\end{array}$ & $\begin{array}{l}\text { NPA as } \% \text { age } \\
\text { to total loans } \\
\mathrm{O} / \mathrm{S}\end{array}$ & \\
\hline & 2007-2008 & 1762.60 & 110.32 & 6.26 & 78.06 \\
\hline & 2008-2009 & 15237.77 & 910.07 & 6.0 & 65.14 \\
\hline & 2009-2010 & 22853.97 & 940.66 & 4.12 & 75.71 \\
\hline & 2011-2012 & 46442.27 & 1385.34 & 2.98 & 53.5 \\
\hline \multirow{6}{*}{$\begin{array}{l}\text { Cooperative } \\
\text { Bank }\end{array}$} & & \multicolumn{3}{|c|}{ NPAs of SHGs against Bank Loan } & \multirow{2}{*}{$\begin{array}{l}\% \text { of recovery to } \\
\text { demand of total SHGs } \\
(\%)\end{array}$} \\
\hline & Year & $\begin{array}{l}\text { Total loans outstanding } \\
\text { against SHGs }\end{array}$ & $\begin{array}{l}\text { Amount of } \\
\text { NPAs }\end{array}$ & $\begin{array}{l}\text { NPA as \% age } \\
\text { to total loans } \\
\mathrm{O} / \mathrm{S}\end{array}$ & \\
\hline & 2007-2008 & 458.31 & 14.80 & 3.2 & 67.8 \\
\hline & 2008-2009 & 4239.62 & 231.01 & 5.4 & 62.83 \\
\hline & $2009-2010$ & 5667.72 & 314.49 & 5.55 & 54.74 \\
\hline & 2011-2012 & 8169.80 & 673.97 & 8.25 & 85.2 \\
\hline
\end{tabular}

Source: Status of Microfinance Programme in India for 2007-08, 2008-09, 2009-10 \& 2011-12, NABARD; data's are edited by author

Similarly, through the period of 2007-08 and 2008-09 in NER, the total cooperative bank loans outstanding against SHGs was Rs 458.31 and Rs 4239.62 lakh respectively, and from that, portion of NPAs was $3.2 \%$ and $5.4 \%$. During these periods the percentage of recovery to demand of total SHGs was $67.8 \%$ and $62.83 \%$ respectively. However during the year 2011-12, the total cooperative bank loans outstanding against SHGs increases to Rs 8169.80 lakh and proportion of NPAs increases to $8.25 \%$. During the same time period, the recovery performance was to some extent decreases to $85.2 \%$.

For the duration of period 2007-08 and 2008-09 in SR, the total public sector commercial bank loans outstanding against SHGs was Rs 635786.66 lakh and Rs 1037907.35 lakh respectively, and from that, portion of NPAs was only $1.6 \%$ and $1.1 \%$. During these periods the percentage of recovery to demand of total SHGs was $93.63 \%$ and $91.97 \%$ respectively. Nevertheless during the year 2011-12, the total public sector commercial bank loans outstanding against SHGs increases to Rs 137019.02 lakh and proportion of NPAs increases to $5.11 \%$. During the same time period, the recovery performance was somewhat declines to $86.22 \%$.

The participation of private sector commercial bank was adequate in SR microfinance programmes. Throughout the period of 2007-08 and 2008-09 in SR, the total private sector commercial bank loans against SHGs were Rs 31333.52 lakh and Rs 126004.30 lakh respectively. In that period magnitude of NPAs was $0.3 \%$ and $0.1 \%$ respectively. For the same time period the recovery rate was around $98 \%$. Besides, during the year 2011-12, the private sector commercial bank loans outstanding against SHGs increases to Rs 137019.02 lakh, and magnitude of NPAs was $5.31 \%$. At the same time recovery rate was declines to $86.61 \%$. 
Table- 1.3: NPAs against Bank Loans to SHGs and Recovery Performance of Different type of Bank in Southern Region of India for Four Different Time Period (Amount Rs Lakh)

\begin{tabular}{|c|c|c|c|c|c|}
\hline \multirow{6}{*}{$\begin{array}{l}\text { Type of Bank } \\
\text { Public } \\
\text { Sector } \\
\text { Commercial } \\
\text { Bank }\end{array}$} & \multirow[b]{2}{*}{ Year } & \multicolumn{3}{|c|}{ NPAs of SHGs against Bank Loan } & \multirow{2}{*}{$\begin{array}{l}\text { \% of recovery to } \\
\text { demand of total SHGs } \\
(\%)\end{array}$} \\
\hline & & $\begin{array}{l}\text { Total loans outstanding } \\
\text { against SHGs }\end{array}$ & $\begin{array}{l}\text { Amount of } \\
\text { NPAs }\end{array}$ & $\begin{array}{l}\text { NPA as } \% \text { age } \\
\text { to total loans } \\
\mathrm{O} / \mathrm{S}\end{array}$ & \\
\hline & 2007-2008 & 635786.66 & 10202.24 & 1.6 & 93.63 \\
\hline & 2008-2009 & 1037907.35 & 11859.91 & 1.1 & 91.97 \\
\hline & 2009-2010 & 1390014.94 & 27107.24 & 1.95 & 89.64 \\
\hline & 2011-2012 & 1764511.47 & 90094.41 & 5.11 & 86.22 \\
\hline \multirow{6}{*}{$\begin{array}{l}\text { Private Sector } \\
\text { Commercial } \\
\text { Bank }\end{array}$} & & \multicolumn{3}{|c|}{ NPAs of SHGs against Bank Loan } & \multirow{2}{*}{$\begin{array}{l}\% \text { of recovery to } \\
\text { demand of total SHGs } \\
(\%)\end{array}$} \\
\hline & Year & $\begin{array}{l}\text { Total loans outstanding } \\
\text { against SHGs }\end{array}$ & $\begin{array}{l}\text { Amount of } \\
\text { NPAs }\end{array}$ & $\begin{array}{l}\text { NPA as \% age } \\
\text { to total loans } \\
\mathrm{O} / \mathrm{S}\end{array}$ & \\
\hline & 2007-2008 & 31333.52 & 32.96 & 0.1 & 98.01 \\
\hline & 2008-2009 & 126004.30 & 329.76 & 0.3 & 98.24 \\
\hline & 2009-2010 & 39008.01 & 1662.41 & 4.26 & 95.24 \\
\hline & 2011-2012 & 137019.02 & 7272.37 & 5.31 & 86.61 \\
\hline \multirow{6}{*}{$\begin{array}{l}\text { Regional } \\
\text { Rural Bank }\end{array}$} & & \multicolumn{3}{|c|}{ NPAs of SHGs against Bank Loan } & \multirow{2}{*}{$\begin{array}{l}\% \text { of recovery to } \\
\text { demand of total SHGs } \\
(\%)\end{array}$} \\
\hline & Year & $\begin{array}{l}\text { Total loans outstanding } \\
\text { against SHGs }\end{array}$ & $\begin{array}{l}\text { Amount of } \\
\text { NPAs }\end{array}$ & $\begin{array}{l}\text { NPA as } \% \text { age } \\
\text { to total loans } \\
\mathrm{O} / \mathrm{S}\end{array}$ & \\
\hline & 2007-2008 & 252879.31 & 3023.72 & 1.20 & 92.93 \\
\hline & $2008-2009$ & 217504.24 & 4764.37 & 2.2 & 90.29 \\
\hline & $2009-2010$ & 374464.01 & 4779.40 & 1.28 & 92.48 \\
\hline & 2011-2012 & 520617.75 & 23849.78 & 4.58 & 92.85 \\
\hline \multirow{6}{*}{$\begin{array}{l}\text { Cooperative } \\
\text { Bank }\end{array}$} & & \multicolumn{3}{|c|}{ NPAs of SHGs against Bank Loan } & \multirow{2}{*}{$\begin{array}{l}\% \text { of recovery to } \\
\text { demand of total SHGs } \\
(\%)\end{array}$} \\
\hline & Year & $\begin{array}{l}\text { Total loans outstanding } \\
\text { against SHGs }\end{array}$ & $\begin{array}{l}\text { Amount of } \\
\text { NPAs }\end{array}$ & $\begin{array}{l}\text { NPA as \% age } \\
\text { to total loans } \\
\mathrm{O} / \mathrm{S}\end{array}$ & \\
\hline & $2007-2008$ & 46262.78 & 2272.69 & 4.9 & 85.50 \\
\hline & $2008-2009$ & 56637.53 & 3398.93 & 6.0 & 88.33 \\
\hline & $2009-2010$ & 98801.03 & 2104.32 & 2.13 & 86.92 \\
\hline & 2011-2012 & 117310.32 & 5142.45 & 4.38 & 88.14 \\
\hline
\end{tabular}

Source: Status of Microfinance Programme in India for 2007-08, 2008-09, 2009-10 \& 2011-12, NABARD; data's are edited by author

As well, for the period of 2007-08 and 2008-09 in SR, the total regional rural bank loans outstanding against SHGs was Rs 252879.31 lakh and Rs 217504.24 lakh respectively, and from that, fraction of NPAs was around $2 \%$. In these periods the rate of recovery to demand of total SHGs was $92.93 \%$ and $90.29 \%$ respectively. But during the year 2011-12, the total regional rural bank loans outstanding against SHGs increases to Rs 520617.75 lakh and share of NPAs increases to 4.58\%. During the same time period, the recovery performance was unchanged at $92 \%$.

Identical, in the course of period 2007-08 and 2008-09 in SR, the total cooperative bank loans outstanding against SHGs was Rs 46262.78 lakh and Rs 56637.53 lakh respectively, and share of NPAs was $4.9 \%$ and $6.0 \%$. During these periods the percentage of recovery to demand of total SHGs was $85.50 \%$ and $88.33 \%$ respectively. Further during the year 2011-12, the total cooperative bank loans outstanding against SHGs increases to Rs 117310.32 lakh and proportion of NPAs increases to $4.38 \%$. During the same time period, the recovery performance was to some extent increases to $88.14 \%$.

In this part we analyzed NPAs and recovery performance of SHGs in southern and NER of India. We found that although amount of saving balance of SHGs with banks and amount of loan disbursed to SHGs by banks was lower in NER in compare with SR, but the share of NPAs to total loans outstanding was higher and percentage of recovery to demand of total SHGs was lower in NER. In recent times there has been an improvement of situation of NPAs and recovery rate in NER. However this enhancement was not comparable with SR of India. Consequently, one point come to mind is that, does because of higher NPAs and lower recovery rate, SHGs-BLP had not achieved reasonable achievement in NER of India.

\section{Conclusion}


Entrance to financial markets is important for poor people. Like all economic agents, low-income households and microenterprise can benefit from credit, saving and insurance services. However financial markets, because of their special features, frequently serve poor people badly, since poor people often have insufficient traditional forms of collateral such as physical assets to offer. They are often excluded from traditional financial markets because transaction costs are often high relative to the small loans typically demanded by poor people.

In India, since the early national plans, successive governments have emphasized the link between improving access to finance and reducing poverty. In light of the inefficiencies that characterized India's rural finance markets and the relative lack of success of formal rural finance institutions in delivering finance to the poor, NGOs, financial institutions, and government have made efforts, in partnership, to develop new financial delivery approaches. These approaches or "microfinance" programmes have been designed to overcome some of the risks and costs associated with formal financing, and also to overcome the tyranny of collateral. One approach to microfinance that has gained prominence in recent years is the SHGs-BLP. Over the last ten years, SHGs-BLP has become the dominant mode of microfinance in India, and has been successful in encouraging momentous savings and high repayment rates.

Despite of being successful, there are still disparities in the programme in its level of progress across different regions particularly between NER and SR of the country. We found that in recent years, SR achieved higher amount of saving balance of SHGs with banks in comparison with NER. Similarly, the amount of loan disbursed to SHGs by banks was also higher in SR. Thus logically one point come to mind is that, does amount of NPAs is lower and recovery performance is satisfactory in NER compare to SR. We found that although amount of saving balance of SHGs with banks and amount of loan disbursed to SHGs by banks was lower in NER in compare with SR, but the share of NPAs to total loans outstanding was higher and percentage of recovery to demand of total SHGs was lower in NER. In current times there has been an improvement of situation of NPAs and recovery rate in NER. However this development was not comparable with SR of India. Consequently, one point come to mind is that, does because of higher NPAs and lower recovery rate, SHGsBLP had not achieved reasonable achievement in NER of India.

\section{Journal Papers:}

\section{References}

[1] Basu, Priya \& Srivastava, Pradeep (2005). Exploring Possibilities Microfinance and Rural Credit Access for the Poor in India. Economic \& Political Weekly, April $23^{\text {rd }}$

[2] Bera, Sayantan (2008). Program Design and Impact Assessments: Success of Microfinance in Perspective. Economic and Political Weekly, August $9^{\text {th }}$

[3] Basu, Priya \& Srivastava, Pradeep (2005). Exploring Possibilities Microfinance and Rural Credit Access for the Poor in India. Economic and Political Weekly, April $23^{\text {rd }}$

[4] Dutta, Sankar (2009). Consolidating the Growth of Microfinance. Economic and Political Weekly, July $25^{\text {th }}$ VOL XLIV, NO 30

[5] Dasgupta, Rajaram (2001). An Informal Journey through Self- Help Groups. Indian Journal of Agricultural Economics, VOL. 56, NO. 3, July - Sept.

[6] Dasgupta, Rajaram (2005). Microfinance in India- Empirical Evidence, Alternative Models and Policy Imperatives. Economic and Political Weekly, March $19^{\text {th }}$.

[7] Karmakar, K. G. (2009). Emerging Trends in Microfinance. Economic and Political Weekly, March 28 $8^{\text {th }}$, VOL, XLIV NO. 13.

[8] Nair, S. Tara (2001). Institutionalizing Microfinance in India- An Overview of Strategic Issues. Economic and Political Weekly, January $27^{\text {th }}$

[9] Sriram, M.S (2005). Microfinance and the State Exploring Areas and Structural of Collaborating. Economic and Political Weekly, April $23^{\text {rd }}$.

[10] Sriram, M.S (2005). Information Asymmetry and Trust; A Framework for Studying Microfinance in India. Vikalpa, Volume 30. No 4. October-December 2005.

[11] Shivamaggi, H.B (2000). Reforms in Rural Banking; Need for Bolder Approach. Economic \& Political Weekly, 13 May.

[12] Umdor, Sumarbin (2008). Behavior of Rural Households in the Borrowing and Usage of Credit in North-East Uplands of India. Indian Journal of Agricultural Economics, Vol. 63, No. 2

Books

[1] Das, Tiken (2012). A Region-Wise Analysis of Microfinance Programme in India. Germany: Lap Lambert Academic Publishing.

[2] Ghate, Prabhu (2007). Indian Microfinance- The Challenges of Rapid Growth.New Delhi: SAGE Publication.

[3] Karmakar, K.G (2008). Microfinance in India. New Delhi: SAGE Publication.

[4] Reddy, Y.V, Tarapora, S.S \& Ahluwalia, Montek S (2002). Macroeconomics and Monetary Policy Issues for a Reforming Economy. Oxford University Press.

\section{Proceedings Papers:}

[1] Asian Development Bank (ADB). (2000). Finance for the Poor; Microfinance Development Strategy.

[2] Basu, Priya (2006). Improving Access to Finance for India's Rural Poor. The World Bank Report 36448.

[3] Bansal, Hema (2003). SHG- Bank Linkage Program in India, An Overview

[4] Basu, Priya \& Srivastava, Pradeep (2005). Scaling-Up Microfinance for India's Rural Poor. World Bank Policy Research Working Paper 3646, June, 2006

[5] Chakrabarti, Rajesh (2005). The Indian Microfinance Experience-Accomplishments and Challenges 
[1] Moulick, Madhurantika (2008). Understanding and Responding to the Savings Behavior of the Low Income People in the North East Region of India, Micro Save-Market-led Solutions for Financial Services. www.microsave.org.

[2] Manak, Sandeep \& Reddy, C.S (2005). Self-Help Groups; A Keystone of Microfinance in India- Women Empowerment and Social Security. www.apmas.org.

[3] Umdor, Sumarbin (2008). Microfinance Program in North East India. Manipur Research Forum, Delhi. www.manipurresearchforum.

\section{Reports}

[1] National Bank for Agriculture and Rural Development (NABARD). (2007-08). Status of Microfinance Programme in India 2007-08. Mumbai, India

[2] National Bank for Agriculture and Rural Development (NABARD). (2008-09). Status of Microfinance Programme in India 2008-09. Mumbai, India

[3] National Bank for Agriculture and Rural Development (NABARD). (2010-11). Status of Microfinance Programme in India 2010-11. Mumbai, India

[4] National Bank for Agriculture and Rural Development (NABARD). (2011-12). Status of Microfinance Programme in India 2011-12. Mumbai, India 